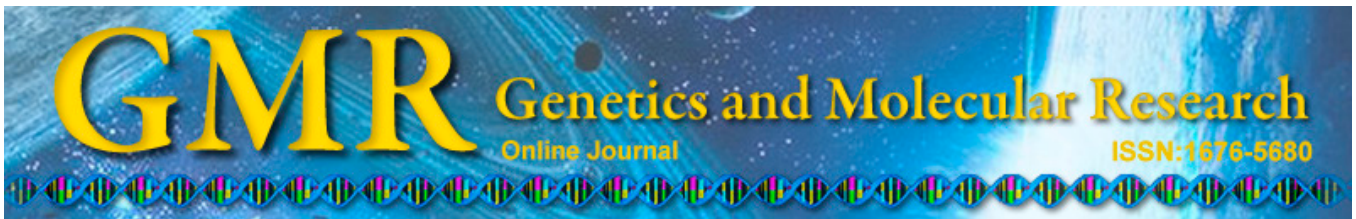

\title{
Genetic diversity of the endemic flat-needle pine Pinus krempfii (Pinaceae) from Vietnam revealed by SSR markers
}

\author{
D.T. Phong', T.T. Lieu', V.T.T. Hien ${ }^{1}$ and N.T. Hiep ${ }^{2}$ \\ ${ }^{1}$ Department of Experimental Taxonomy and Genetic Diversity, \\ Vietnam National Museum of Nature, \\ Vietnam Academy of Science and Technology, Cau Giay, Hanoi, Vietnam \\ ${ }^{2}$ Center for Plant Conservation, \\ Vietnam Union of Science and Technology Associations, \\ Cau Giay, Hanoi, Vietnam \\ Corresponding author: D.T. Phong \\ E-mail: dinhthiphong@hotmail.com
}

Genet. Mol. Res. 14 (3): 7727-7739 (2015)

Received October 24, 2014

Accepted April 7, 2015

Published July 13, 2015

DOI http://dx.doi.org/10.4238/2015.July.13.19

\begin{abstract}
Pinus krempfii Lecomte (Pinaceae) is an endemic tree to Vietnam with restricted habitats at higher altitudes in the highlands. In this study, genetic variation of four populations of $P$. krempfii was assessed using 17 microsatellite markers (single sequence repeats). Of these 17 markers, eight were polymorphic, and among the 42 putative alleles amplified, 32 were polymorphic (accounting for $76.19 \%$ ). The Cong Troi population was found to be the most genetically diverse (Shannon's information index, $I=0.415$, and percentage of polymorphic bands, $P P B=52.95 \%$ ), whereas the Hon Giao population was found to have the lowest diversity $(I=0.330$ and $P P B=47.06 \%)$. The genetic diversity at species level was also estimated $(I=0.414, P P B=76.19 \%)$. Molecular variance was found to be low among populations (11.94\%) and high among individuals within the populations (88.06\%). Private alleles were not detected in the Hon Giao population. The Yang Ly population
\end{abstract}


had a positive $F_{\text {IS }}$ (inbreeding coefficient) value of 0.071 , while the three remaining populations had negative values (-0.116 for Cong Troi, -0.316 for Chu Yang Sin, and -0.350 for Hon Giao). The results obtained show an excess of homozygosity in the Yang Ly population, and also suggest a deficiency of heterozygosity for this population. Several approaches and measures of conservation for P. krempfii are discussed and proposed.

Key words: Endemic species; Genetic diversity; Pinus krempfi; Population structure; SSR markers

\section{INTRODUCTION}

Pinus krempfii Lecomte is a unique flat pine species endemic to Vietnam. P. krempfii not only has an important role within the forest ecosystem but it is also of great commercial value, with wood, plastic, oil, and pharmaceutical applications. The chemical constituents of P. krempfii were reported in 2014 (Nhung et al., 2014). This species can only grow in restricted habitats at higher altitudes in the border areas of Dak Lak, Lam Dong, and Khanh Hoa Provinces. Although its estimated extent of occurrence is within the threshold for endangered species, and its area of occupancy is also likely to be less than $500 \mathrm{~km}^{2}$, there are more than five locations known and the subpopulations are not currently considered severely fragmented (Wang et al., 2000; Thomas et al., 2013). P. krempfii grows as a large emergent tree at altitudes between 1200-2000 m; it is always at the top or on the upper slopes of flattened ridges. The surrounding forests are typically dominated by evergreen members of the Fagaceae and Lauraceae. P. krempfii is often associated with Fokienia hodginsii, Pinus dalatensis, and Podocarpus neriifolius. $P$. krempfii is unusual amongst the pines as young trees can persist under an evergreen canopy and compete with angiosperm trees (Brodribb and Field, 2008). The rarity of this species has prevented its direct exploitation in the past. Nowadays, its presence within one of Vietnam's flagship protected areas under legal protection appears to be a good measure of conservation; however, low genetic polymorphism and restricted distribution of $P$. krempfii have put this tree under the threat of extinction. The extent of occurrence of $P$. krempfii has declined by more than $30 \%$ over the last three generations (150 years) as a result of deforestation and conversion of forests to other uses (Thomas et al., 2013). According to a recent survey by Thomas et al. (2013), only several, i.e., less than ten, natural populations of $P$. krempfii still exist in Vietnam. There is evidence of a continuing decline in the quality of habitat in some locations due to the effects of habitat fragmentation, illegal logging, and infrastructure development. On this basis, P. krempfii is assessed as vulnerable under criteria A2c and B1ab(iii) of the IUCN (International Union for the Conservation of Nature and Natural Resources) Red List of threatened species (Thomas et al., 2013).

In 1921, a pine-like evergreen conifer was discovered in the mountains of southern Vietnam and was described by Lecomte (1921) as P. krempfii. P. krempfii is a large tree, reaching heights of up to $30 \mathrm{~m}$ and with a trunk diameter up to $80 \mathrm{~cm}$ (Figure 1) (Nguyen and Vidal, 1996). Unlike any other pine, P. krempfii is characterized by having two flat leaf-like needles rather than typical pine-like needles (Lecomte, 1921). The distribution of P. krempfii in Vietnam is very limited. It is found only in some localities of Khanh Hoa and Lam Dong Provinces at elevations of 1200-2000 m (Nguyen, 1993). It occurs naturally in tropical mixed broadleaf forests, occasionally together with P. dalatensis, Pinus merkusii, and Pinus kesiya (Vu, 1996). 
P. krempfii occurs in small groups of 10-30 trees and grows together with species of Fagaceae, Magnoliaceae, Lauraceae, Cryptocarya sp, Illicium sp, Rhodoleia sp, and Podocarpus sp, which form very dense forests (Nguyen, 1993). The most serious long term threat to P. krempfii is habitat fragmentation resulting from infrastructure developments, an increasing incidence of fires throughout the region, the conversion of lower altitude forests to fire-prone $P$. kesiya forests, and encroachment into protected areas for coffee production. Furthermore, illegal logging aimed at P. krempfii in Chu Yang Sin has recently been reported (Thomas et al., 2013).

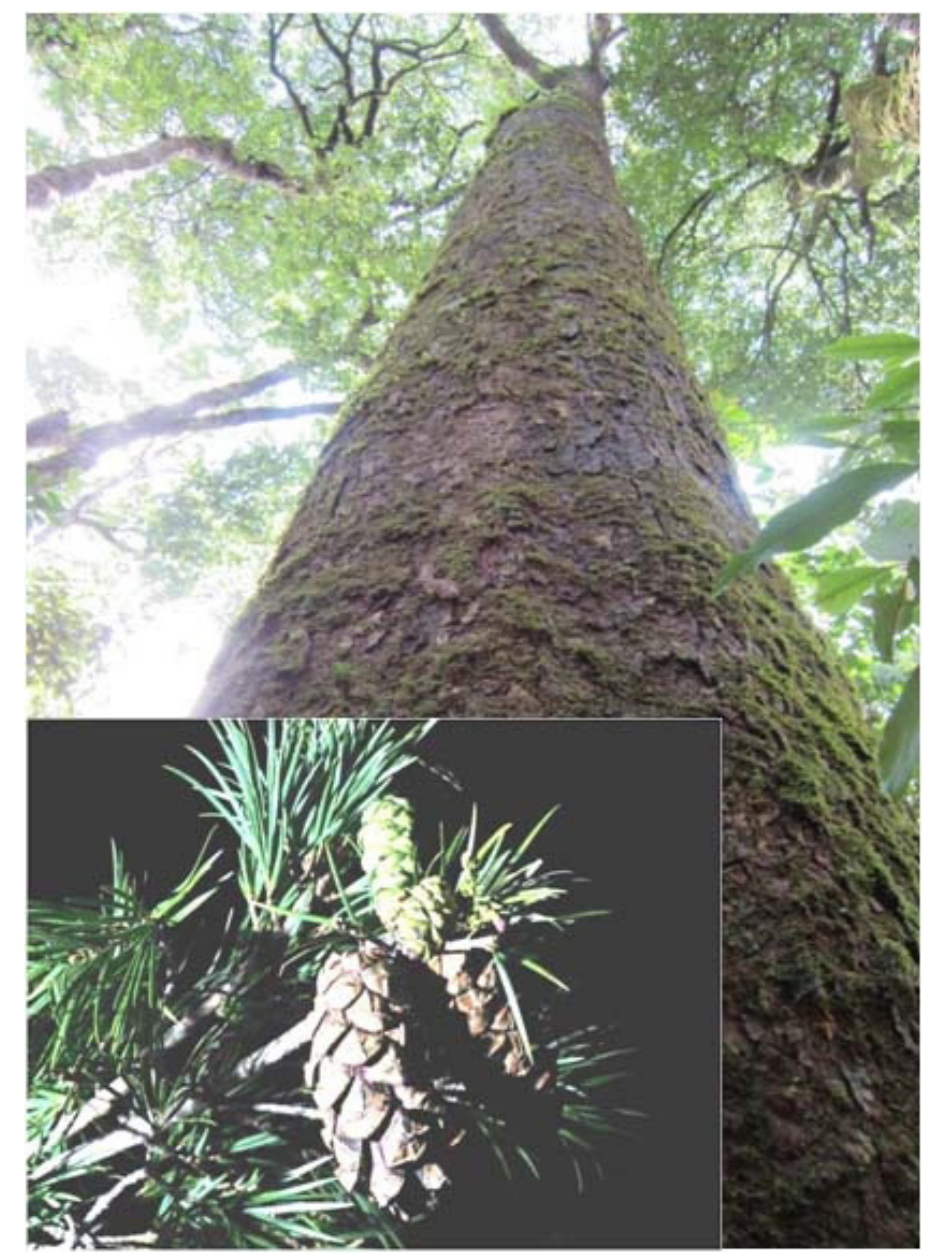

Figure 1. Adult tree and twigs with cone of Pinus krempfii in Lam Dong Province, Vietnam (Photographs by Nguyen Tien Hiep).

Genetic markers have been used to study the phylogenetic position of P. krempfii and have revealed its status as a member of the subgenus Strobus (Willyard et al., 2007; Parks et al., 2012; Wang et al., 2000, 2014). However, only limited individuals of $P$. krempfii were included in these studies, and the levels and patterns of DNA variation within natural populations remain unclear. 
Genetic variation must exist to maintain natural populations as evolutionarily viable units capable of adapting to changing environmental conditions in the long term. Thus, a genetic resource management strategy should involve investigation of genetic diversity and the extent of genetic differentiation within and between populations and have an understanding of the processes that maintain these variations. To our knowledge, there is no research to date focusing on the genetic diversity and population structure of $P$. krempfii, a species endemic to Vietnam. For this reason, the objectives of this study were to i) characterize the genetic diversity and genetic differentiation of $P$. krempfii populations using microsatellite markers (single sequence repeats, SSR) markers; ii) characterize the genetic structure in the populations, and iii) offer an effective conservation strategy for P. krempfii.

\section{MATERIAL AND METHODS}

\section{Plant materials}

This research was carried out at four sites in Vietnam, three in Lam Dong Province and one in Dak Lak Province (Table 1 and Figure 2). Leaf samples or inner bark samples of $P$. krempfii individuals were collected at random from natural stands, including from the Bidoup Nui Ba National Park, Lam Dong Province and the Chu Yang Sin National Park, Dak Lak Province.

Table 1. Details of Pinus krempfii genotypes and populations from Vietnam used in this study.

\begin{tabular}{lclccc}
\hline Population code & Sample size & Collection locality & Latitude $\left({ }^{\circ} \mathrm{N}\right)$ & Longitude $\left({ }^{\circ} \mathrm{E}\right)$ & Elevation $(\mathrm{m})$ \\
\hline Yang Ly & 5 & Yang Ly, Bidoup Nui Ba, Lam Dong & $12^{\circ} 11^{\prime} 02.7^{\prime \prime} \mathrm{N}$ & $108^{\circ} 41^{\prime} 24.3^{\prime \prime} \mathrm{E}$ & $1482-1485$ \\
Cong Troi & 11 & Cong Troi, Bidoup Nui Ba, Lam Dong & $12^{\circ} 05^{\prime} 17.9^{\prime \prime} \mathrm{N}$ & $108^{\circ} 22^{\prime} 13.0^{\prime \prime} \mathrm{E}$ & $1659-1757$ \\
HònGiao & 26 & Hon Giao, Bidoup Nui Ba, Lam Dong & $12^{\circ} 11^{\prime} 03.2^{\prime \prime} \mathrm{N}$ & $108^{\circ} 41^{\prime} 30.3^{\prime \prime} \mathrm{E}$ & $1482-1593$ \\
Chu Yang Sin & 28 & Hoa Son, Chu Yang Sin, Dak Lak & $12^{\circ} 25^{\prime} 05.2^{\prime \prime} \mathrm{N}$ & $108^{\circ} 22^{\prime} 17.1^{\prime \prime} \mathrm{E}$ & $1110-1120$ \\
\hline
\end{tabular}

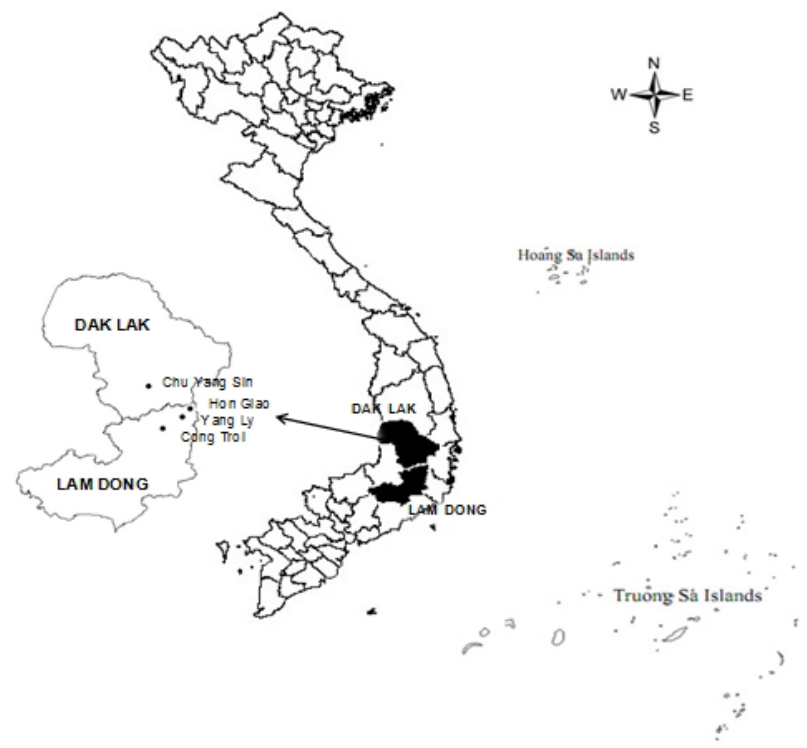

Figure 2. Location of the Pinus krempfii populations used in this study, in Vietnam. 
Bidoup Nui Ba National Park is the largest of Vietnam's nature preserves and one of seven internationally important Centers of Plant Diversity in Vietnam. This park encompasses over $1000 \mathrm{~km}^{2}$ and extends from eastern Cambodia into northern Dak Lak and southern Gia Lai Province in Vietnam. Most of the topography of this park is flat, with an elevation of approximately $1200-2000 \mathrm{~m}$. National Park Bidoup Nui Ba is one of 28 national parks in the system of special-use forests in Vietnam. Of the 64,800 ha that comprise National Park Bidoup Nui Ba, $91 \%$ are forests or forest land, which are mainly composed of primeval forest with many different plant and animal species. Chu Yang Sin National Park is located in the territory of the Lak and Krong Bong districts of Dak Lak and is $60 \mathrm{~km}$ to the east of Buon Ma Thuot city. The center of the National Park is Mount Chu Yang Sin at $2442 \mathrm{~m}$ high, the highest peak of the mountain system of southern Truong Son. Chu Yang Sin National Park is a natural area of 58,947 ha. The topography of the national park is characterized by steep slopes and narrow valleys. At elevations below $800 \mathrm{~m}$, the national park supports lowland semi-evergreen forest.

In the field, samples were placed into plastic bags with silica gel and then taken to the Department of Experimental Taxonomy and Genetic Diversity, Vietnam National Museum of Nature, and maintained at room temperature until use.

\section{DNA extraction}

Seventy P. krempfii genotypes were used in this study (coded from Pk1 to Pk70). Total genomic DNA was isolated from leaves and inner bark using the method described by Porebski et al. (1997). The concentration of DNA was determined using a UV-visible light spectrophotometer (UVS 2700, Labomed, USA), and the DNA samples were diluted to $20 \mathrm{ng}$ / $\mu \mathrm{L}$ and used as templates for polymerase chain reaction (PCR) amplification.

\section{SSR marker amplification}

SSR primers were obtained from Integrated DNA Technologies, USA (Table 2). PCR amplifications were performed in a final volume of $25 \mu \mathrm{L}$ with $50 \mathrm{ng}$ DNA, 1 U Taq polymerase (Platinum Taq DNA Polymerase, Invitrogen, USA), $2.5 \mathrm{mM} \mathrm{MgCl}, 0.2 \mathrm{mM}$ of each dNTP, $2.5 \mu \mathrm{L}$ 10X PCR buffer (Invitrogen), and $0.5 \mathrm{mM}$ of each primer. The PCR protocol consisted of 1 cycle at $94^{\circ} \mathrm{C}$ for $3 \mathrm{~min}, 40$ cycles at $94^{\circ} \mathrm{C}$ for $30 \mathrm{~s}, 50-58^{\circ} \mathrm{C}$ (see Table 2) for 1 min, and $72^{\circ} \mathrm{C}$ for $1 \mathrm{~min}$. SSR fragments were detected on a $5 \%$ polyacrylamide gel in $0.5 \mathrm{X}$ TBE. The gels were visualized under UV using BioDocAnalyze (Biometra, Germany).

\section{Data analysis}

For each SSR locus, the allelic composition and total number of alleles were determined for each accession. Data were entered in the form of single-individual genotypes. Genetic polymorphism for each population was assessed using the programs GENALEX version 6 (Peakall and Smouse, 2005), FSTAT (Goudet, 1995), and POPGENE (Yeh et al., 1999). The percentage of polymorphic bands $(P P B)$, Shannon's information index $(I)$, the mean of expected heterozygosity $\left(H_{\mathrm{E}}\right)$, the mean of observed heterozygosity $\left(H_{\mathrm{O}}\right)$, and the inbreeding coefficient $\left(F_{\text {IS }}\right)$ were calculated. The coefficient of gene differentiation $\left(F_{\mathrm{ST}}\right)$ and gene flow $\left(N_{\mathrm{m}}\right)$ between the SSR loci were also calculated using the GENALEX 6.3 program with the following equations:

$$
F_{\text {st }}=\left(H_{\mathrm{T}}-\text { mean } H_{\mathrm{E}}\right) / H_{\mathrm{T}} \quad \text { (Equation 1) }
$$




$$
N_{\mathrm{m}}=\left[\left(1 / F_{\mathrm{ST}}\right)-1\right] / 4
$$

(Equation 2)

where, $H_{\mathrm{E}}=1-\sum(p i)^{2}, H_{\mathrm{T}}=$ total expected heterozygosity $=1-\sum(t p i)^{2}(p i$ is the frequency of the $i^{\text {th }}$ allele, tpi is the frequency of the $i^{\text {th }}$ allele for the total). Exact tests of deviation from the Hardy-Weinberg equilibrium for all loci and among populations were performed at the significance level $(\mathrm{P})$ of 0.001 .

Table 2. Characteristics of 17 microsatellite (SSR) markers used to amplify sections of the Pinus krempfii genome.

\begin{tabular}{|c|c|c|c|c|}
\hline Locus & Primer sequences & $\operatorname{Tm}\left({ }^{\circ} \mathrm{C}\right)$ & References & Size (bp) \\
\hline NZPR6 & $\begin{array}{l}\text { 5'-GGAAGAAAAATTGGGCCTTA-3' } \\
\text { 3'-CTCTCTATCTCTGCCCCA-5' }\end{array}$ & 51 & Echt et al., 1999 & 230 \\
\hline Pt79951 & $\begin{array}{l}\text { 5'-CTTTTGTTTTTCAACAATTGCA-3' } \\
\text { 3'-ACATCTATCTCCCATATCGGC-5' }\end{array}$ & 50 & Vendramin et al., 1996 & 155 \\
\hline Pt36480 & $\begin{array}{l}\text { 5'-TTTTGGCTTACAAAATAAAAGAGG-3' } \\
\text { 3'-AAATTCCTAAAGAAGGAAGAGCA-5' }\end{array}$ & 58 & Clark et al., 2000 & $155-157$ \\
\hline P5 & $\begin{array}{l}\text { 5'-GTTCGCTAGTTTGTTTGATCCC-3' } \\
\text { 3'-TCCCAGCAAATCCTTGACTC-5' }\end{array}$ & 58 & Soranzo et al., 1999 & 400 \\
\hline Pt9383 & $\begin{array}{l}\text { 5'-AGAATAAACTGACGTAGATGCCA-3' } \\
\text { 3'-ATTTTCAATTCCTTTCTTTCTCC-5' }\end{array}$ & 50 & Clark et al., 2000 & $105-110$ \\
\hline PtTX3026 & $\begin{array}{l}\text { 5'-AATACTTGGGAGGGATAC-3' } \\
\text { 3'-AATAGCCAGTTTTGTTTG-5' }\end{array}$ & 52 & Elsik et al., 2000 & $320-495$ \\
\hline Pt26081 & $\begin{array}{l}\text { 5'-CCCGTATCCAGATATACTTCCA-3' } \\
\text { 3'-TGGTTTGATTCATTCGTTCAT-5' }\end{array}$ & 54 & Vendramin et al., 1996 & $105-130$ \\
\hline Pt30204 & $\begin{array}{l}\text { 5'-TCATAGCGGAAGATCCTCTTT-3' } \\
\text { 3'-CGGATTGATCCTAACCATACC-5' }\end{array}$ & 52 & Vendramin et al., 1996 & $120-165$ \\
\hline Pt71936 & $\begin{array}{l}\text { 5'-TTCATTGGAAATACACTAGCCC-3' } \\
\text { 3'-AAAACCGTACATGAGATTCCC-5' }\end{array}$ & 58 & Vendramin et al., 1996 & $150-160$ \\
\hline Pt87268 & $\begin{array}{l}\text { 5'-GCCAGGGAAAATCGTAGG-3' } \\
\text { 3'-AGAAGATTAGACATCCAACCC-5' }\end{array}$ & 58 & Vendramin et al., 1996 & 400 \\
\hline Pt15196 & $\begin{array}{l}\text { 5'-CTTGGATGGAATAGCAGCC-3' } \\
\text { 3'-GGAAGGGCATTAAGGTCATTA-5' }\end{array}$ & 52 & Vendramin et al., 1996 & 160 \\
\hline Pnh038 & $\begin{array}{l}\text { 5'-ACTCATTTCCGGATGGTGG-3' } \\
\text { 3'-TGGGGCTTGGACTTCAAGA-5' }\end{array}$ & 50 & Chiang et al., 2011 & 160 \\
\hline PeC26BGT & $\begin{array}{l}\text { 5'-CATCCACCAGTTTCCCTACG-3' } \\
\text { 3'-ATTTGAACGCACAGAGCATTT-5' }\end{array}$ & 51 & Mellick et al., 2009 & 185 \\
\hline PRE24 & $\begin{array}{l}\text { 5'-GTTTTTTAAATTGGGAAGGCG-3' } \\
\text { 3'-CGTGGGGGAGATAGTGATAGAGT-5' }\end{array}$ & 58 & Boys et al., 2005 & $280-400$ \\
\hline PtTX3020 & $\begin{array}{l}\text { 5'-GTCGGGGAAGTGAAAGTA-3' } \\
\text { 3'-CTAGGTGCAAGAAAAGAGTAT-5' }\end{array}$ & 50 & Elsik et al., 2000 & $165-270$ \\
\hline RPS2 & $\begin{array}{l}\text { 5'-CATGGTGTTGGTCATTGTTCCA-3' } \\
\text { 3'-TGGAGGCTATCACGTATGCACC-5' }\end{array}$ & 50 & Echt et al., 1996 & $140-500$ \\
\hline RPS160 & $\begin{array}{l}\text { 5'-ACTAAGAACTCTCCCTCTCACC-3' } \\
\text { 3'-TCATTGTTCCCCAAATCAT-5' }\end{array}$ & 56 & Echt et al. 1996 & 250 \\
\hline
\end{tabular}

Analysis of molecular variance (AMOVA) was conducted to calculate levels of significant variation among the four distribution regions, among populations within a region, and within populations using GENALEX 6.3. Genetic distances and identities and UPGMA cluster analysis were generated to determine the genetic association among populations based on Nei's genetic distance (Nei, 1972) using POPGENE.

\section{RESULTS}

Of the 17 SSR markers used, 8 were found to be polymorphic and among the 42 putative genetic alleles that were amplified, 32 were polymorphic (accounting for $76.19 \%$ ). Both the indices $I$ and $P P B$ were used to assess genetic diversity (Table 3), with the highest diversity 
observed in the Cong Troi population $(I=0.415$ and $P P B=52.95 \%$ ), followed by the Chu Yang Sin population $(I=0.390$ and $P P B=52.94 \%)$, the Yang Ly population $(I=0.373$ and $P P B=$ $52.93 \%)$, and the lowest diversity in the Hon Giao population $(I=0.330$ and $P P B=47.06 \%)$. Genetic diversity at the species level was also determined $(I=0.414, P P B=76.19 \%)$.

Table 3. Genetic diversity parameters of the Pinus krempfii populations analyzed.

\begin{tabular}{lcc}
\hline Population & $I$ & $P P B(\%)$ \\
\hline Yang Ly & 0.373 & 52.93 \\
Cong Troi & 0.415 & 52.95 \\
Hon Giao & 0.330 & 47.06 \\
Chu Yang Sin & 0.390 & 52.94 \\
Mean & 0.377 & 51.47 \\
At the species level & 0.414 & 76.19 \\
\hline
\end{tabular}

$I=$ Shannon's information index; $P P B=$ percentage of polymorphic bands.

The degree of molecular variation was found to be low among populations $(11.94 \%)$ and high among individuals within populations $(88.06 \%$ ), with a $\mathrm{P}$ value $<0.001$ (Table 4 ). To date, the genetic diversity of $P$. krempfii has not been assessed; however, in comparison to Glyptostrobus pensilis from Vietnam, molecular variation between populations of $P$. krempfii was lower $(33.69 \%)$ but molecular variation among individuals within populations was higher (66.31\%) (Tam et al., 2013).

Table 4. Analysis of molecular variance among/within Pinus krempfii populations.

\begin{tabular}{|c|c|c|c|c|c|}
\hline Source of variance & Degrees of freedom & Sum of squares & Variance components & Total variation (\%) & $P$ value \\
\hline Among population & 3 & 19.992 & 0.289 & 11.94 & $<0.001$ \\
\hline Within population & 66 & 140.693 & 2.132 & 88.06 & \\
\hline
\end{tabular}

Table 5 shows the genetic diversity within the four populations. The mean number of alleles per locus ranged from 1.765 (Yang Ly) to 2.118 (Chu Yang Sin), with a mean of 1.912. The effective number of alleles ranged from 1.477 (Chu Yang Sin) to 1.667 (Cong Troi), with a mean of 1.529. Only three populations were found to have private alleles; Yang Ly (0.059), Cong Troi (0.118), and Chu Yang Sin (0.294). $H_{\mathrm{E}}$ was low within the four populations $(0.200$ $0.250)$ and at the species level $(0.234)$, with the highest $H_{\mathrm{E}}$ in the Cong Troi population $(0.250)$, and lowest in the Hon Giao population (0.200; Table 5).

Table 5. Number of alleles, number of haplotypes and genetic variation within Pinus krempfii populations.

\begin{tabular}{lccccccr}
\hline Population & $\mathrm{N}$ & $N_{\mathrm{A}}$ & $N_{\mathrm{E}}$ & $A_{\mathrm{P}}$ & $H_{\mathrm{O}}$ & $H_{\mathrm{E}}$ & $F_{\text {IS }}$ \\
\hline Yang Ly & 5 & 1.765 & 1.518 & 0.059 & 0.271 & 0.233 & 0.071 \\
Cong Troi & 11 & 1.941 & 1.667 & 0.118 & 0.316 & 0.250 & -0.116 \\
Hon Giao & 26 & 1.824 & 1.455 & 0.000 & 0.292 & 0.200 & -0.350 \\
Chu Yang Sin & 28 & 2.118 & 1.477 & 0.294 & 0.332 & 0.235 & -0.316 \\
Mean & 17.5 & 1.912 & 1.529 & 0.118 & 0.303 & 0.229 & -0.177 \\
At the species level & 70 & 2.471 & 1.521 & - & 0.310 & 0.234 & - \\
\hline
\end{tabular}

$\mathrm{N}=$ population size; $N_{\mathrm{A}}=$ mean No. of alleles per locus; $N_{\mathrm{E}}=$ effective No. of alleles per locus; $A_{\mathrm{P}}=$ private No. of alleles per locus; $H_{\mathrm{O}}$ and $H_{\mathrm{E}}=$ mean of observed and expected heterozygosities; $F_{\text {IS }}=$ Wright's inbreeding coefficient with $\mathrm{P}<0.05$. 
At the population level, in all populations studied, only Yang Ly had a positive $F_{\text {IS }}$ value of 0.071 , while the three remaining populations had negative values $(-0.116$ for Cong Troi, -0.350 for Hon Giao, and -0.316 for Chu Yang Sin), with a P value $<0.05$ (Table 5). The obtained results suggest an excess of homozygosity and inbreeding in the Yang Ly population.

Further, of the 17 SSR markers analyzed, eight (PRE24, PtTX3020, Pt36480, Pt9383, PtTX3026, Pt26081, Pt30204, and RPS2) were found to be polymorphic (Table 6). Among these, the number of unique alleles was highest for marker Pt9383 $\left(N_{\mathrm{m}}=10.796\right.$ and $F_{\mathrm{ST}}=$ $0.023)$, and lowest for marker Pt26081 $\left(N_{\mathrm{m}}=1.813\right.$ and $\left.F_{\mathrm{ST}}=0.121\right)$ for the population $P$. krempfii. The number of different alleles at species level resulted in $N_{\mathrm{m}}$ and $F_{\mathrm{ST}}$ values of 4.919 and 0.064 , respectively.

\section{Table 6. The genetic parameters of all Pinus krempfii populations for eight polymorphic microsatelliteloci.}

\begin{tabular}{lcccccr}
\hline Primers & $N_{A}$ & $N_{\mathrm{E}}$ & $H_{\mathrm{O}}$ & $H_{\mathrm{E}}$ & $F_{\text {ST }}$ & $N_{\mathrm{m}}$ \\
\hline PRE24 & 4.500 & 3.505 & 0.872 & 0.686 & 0.052 & 4.520 \\
PtTX3020 & 3.500 & 2.507 & 0.953 & 0.592 & 0.047 & 5.085 \\
Pt36480 & 2.000 & 1.361 & 0.181 & 0.240 & 0.076 & 3.049 \\
Pt9383 & 2.000 & 1.917 & 0.694 & 0.476 & 0.023 & 10.796 \\
PtTX3026 & 2.500 & 1.568 & 0.327 & 0.345 & 0.071 & 3.272 \\
Pt26081 & 1.750 & 1.362 & 0.144 & 0.237 & 0.121 & 1.813 \\
Pt30204 & 2.500 & 1.321 & 0.161 & 0.240 & 0.029 & 8.428 \\
RPS2 & 3.750 & 2.454 & 0.812 & 0.584 & 0.095 & 2.391 \\
Mean & 2.813 & 1.999 & 0.518 & 0.425 & 0.064 & 4.919 \\
\hline
\end{tabular}

$N_{\mathrm{A}}=$ number of different alleles; $N_{\mathrm{E}}=$ number of effective alleles; $H_{\mathrm{O}}=$ observed heterozygosity; $H_{\mathrm{E}}=$ expected heterozygosity; $F_{\mathrm{ST}}=$ coefficient of gene differentiation; $N_{\mathrm{m}}=$ gene flow.

Pairwise Nei's genetic distance and identity were calculated for all populations (Table 7). The largest distance (0.098) was recorded between the populations of Yang Ly and Hon Giao and the smallest (0.030) between the populations of Hon Giao and Chu Yang Sin. The mean values of genetic distance between the studied populations ranged from 0.030 to 0.098 , with a mean of 0.056 . Similar to the results for genetic distance, the largest genetic identity (0.970) was found between the populations of Chu Yang Sin and Hon Giao, and the smallest (0.906) between the populations of Hon Giao and Yang Ly. The mean value of genetic identity between the populations ranged from 0.906 to 0.970 , with a mean of 0.936 . The obtained values of genetic distance indicate a low level of differentiation among the three populations in Lam Dong Province.

Table 7. Nei's genetic identity (above diagonal) and genetic distance (below diagonal) for four Pinus krempfii populations.

\begin{tabular}{lcccc}
\hline & Yang Ly & Cong Troi & Hon Giao & Chu Yang Sin \\
\hline Yang Ly & & 0.947 & 0.906 & 0.907 \\
Cong Troi & 0.054 & & 0.944 & 0.942 \\
Hon Giao & 0.098 & 0.058 & & 0.970 \\
Chu Yang Sin & 0.097 & 0.060 & 0.030 & \\
\hline
\end{tabular}

The UPGMA dendrogram (Figure 3) revealed genetic relationships among all populations investigated on the basis of the matrix of Nei's genetic distances between populations (Table 7). The four populations were divided into two major groups: the first group contained 
only the Chu Yang Sin population of Dak Lak Province, and showed a relationship to the three other populations with genetic distances from 0.030 to 0.097 . The second group contained the 3 populations of Lam Dong Province (Yang Ly, Cong Troi, and Hon Giao). The 2 populations of Yang Ly and Cong Troi were clustered together, with low genetic distance (0.054). Generally, populations from the same region tended to cluster together $(\mathrm{P}<0.001)$. The low distance between Yang Ly, Cong Troi, and Hon Giao is logical in Lam Dong Province, suggesting that the three populations share the same geological origin compared with the Chu Yang Sin population in Dak Lak Province.

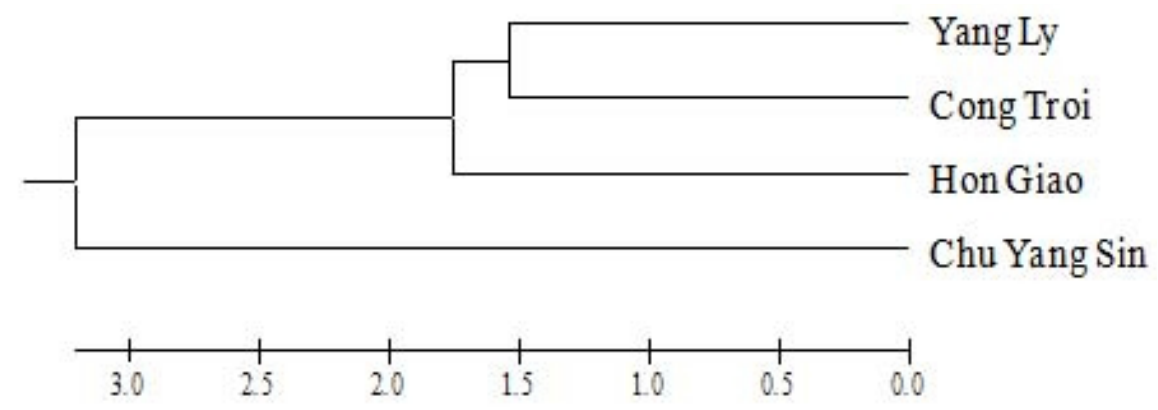

Figure 3. UPGMA dendrogram based on Nei's genetic distance among four populations of Pinus krempfii.

\section{DISCUSSION}

\section{Genetic divergence}

Our first aim was to examine the genetic diversity, genetic differentiation, and population structure of $P$. krempfii. This species only grows in restricted habitats at higher altitudes in Vietnam's highlands, and is currently listed as vulnerable under the IUCN Red List of threatened species (Thomas et al., 2013). Most recently, the genetic diversity of populations of $P$. krempfii in Vietnam was also identified by Wang et al. (2014). In that study, 57 P. krempfii individuals were sampled from six natural populations and analyzed with respect to their sequence variation at ten nuclear gene regions (approximately $9 \mathrm{~kb}$ ), 14 mitochondrial DNA (mtDNA) regions (approximately $10 \mathrm{~kb}$ ), and seven chloroplast microsatellite (SSR) loci. The results showed very low nucleotide diversity at nuclear loci $(0.0020)$ compared with Pinus cembra (0.0024) (Mosca et al., 2012). Furthermore, all investigated populations were monomorphic across all mtDNA regions, which have been identified as polymorphic in other pine species. Wang et al. (2014) also showed that the differentiation among P. krempfii populations at nuclear loci was very low (5.2\%).

Compared to previous genetic diversity research in other Pinus species, Vietnamese $P$. krempfii showed the genetic diversity higher $(P P B=76,19 \%$ and $I=0.414)$ than Pinus nigra in China $(P P B=51.04 \%$ and $I=0.262)$, but lower than Pinus sylvestris in Portugal, Germany, and northern and southern Spain $(P P B=99.76 \%$ and $I=0.690)$ for ISSR markers (RubioMoraga et al., 2012; Cipriano et al., 2013).

The results obtained in the present study indicate high levels of genetic diversity within populations of $P$. krempfii in natural tropical mixed broadleaf forest in highland of Vietnam. The $H_{\mathrm{O}}$ values of $0.271-0.332$, with a mean of 0.303 , reported here are higher than those ob- 
served for some other Pinus species using microsatellite markers. For example, for red pine, $H_{\mathrm{O}}$ ranged from 0.067-0.317 with a mean of 0.185 (Boys et al., 2005), and for Pinus strobes $H_{\mathrm{O}}$ ranged from 0.125-0.812 with a mean of 0.515 (Echt et al., 1996), but in Pinus radiate $H_{\mathrm{O}}$ values ranged from $0-0.85$ with a mean of 0.625 (Smith and Devey, 1994). The $H_{\mathrm{E}}$ values for P. krempfii are much lower than the $H_{\mathrm{O}}$ values. The highest $H_{\mathrm{E}}$ values were observed in the Cong Troi population (0.250) and the lowest in the Hon Giao population (0.200; Table 5). Total genetic diversity for $P$. krempfii in this study $\left(H_{\mathrm{E}}=0.229\right)$ was higher than $P$. nigra $\left(H_{\mathrm{E}}=\right.$ $0.175)$ and Pinus squamata $\left(H_{\mathrm{E}}=0.029\right)$ (Zhang et al., 2005; Rubio-Moraga et al., 2012) and lower than some other Pinus species, which were similarly analyzed with ISSR markers, such as Pinus tabulaeformis ( $H_{\mathrm{E}}=0.4152$; Wang and Hao, 2010), Pinus koraiensis $\left(H_{\mathrm{E}}=0.3477\right.$; Feng et al., 2006), Pinus sibirica $\left(H_{\mathrm{E}}=0.2699\right.$; Yang et al., 2005), P. sylvestris $\left(H_{\mathrm{E}}=0.2620\right.$; Liu et al., 2005; $H_{\mathrm{E}}=0.217-0.310$; Labra et al., 2006; Table 5). In all populations in the current study, five of the eight loci showed significant heterozygote deficiency. Despite the lower levels of $H_{\mathrm{O}}$ and relatively few polymorphic loci used, the average of 5.25 alleles per locus (data not shown) across the eight polymorphic loci characterized for $P$. krempfii was comparable to or lower than microsatellite-based genetic studies of other pines, including six alleles per locus observed in P. radiate (Smith and Devey, 1994), 5.4 alleles per locus in P. strobes (Echt et al., 1996), and 6.7 alleles per locus in P. sylvestris (Soranzo et al., 1999).

This study showed that genetic diversity of $P$. krempfii was highest in the Chu Yang Sin population and lowest in the Hon Giao population. This may be related to the geographic position of the Chu Yang Sin population in Dak Lak Province compared to the three other populations in Lam Dong Province. During field expeditions, we recognized that most genotypes of the Hon Giao population were younger plants with heights of $10 \mathrm{~m}$. Therefore, these may have originated from a mother tree.

The differences in the levels of genetic diversity among four populations may be related to geographic distribution, the number of populations tested, population size of the species, and the effect of climate change during the last glacial maximum.

Based on the $F_{\text {ST }}$ and $N_{\mathrm{m}}$ values in the present study, gene flow is high and a moderate level of genetic diversity is maintained within the populations; however, this is susceptible to genetic drift. This level of differentiation is comparable to pine species with wide distribution ranges (Slatkin, 1985; Cipriano et al., 2013). Due to the lack of a geographical barrier between sampled populations of $P$. krempfii, the population differentiation in this species could have been caused by the fragmented nature of its distribution. Unlike most other pines, P. krempfii does not form pure stands and individual populations consist of small groups of trees dispersed among dense thickets of other tree species (Luu and Thomas, 2004). These conditions are likely to limit dispersal of its pollen and seeds, and contribute to differentiation between local populations. Furthermore, P. krempfii is distributed in a wet rainforest environment, which could preclude efficient wind pollination (Turner, 2001). High humidity dampens pollen grains, and heavy rains wash away pollen from the air. In summary, despite relative proximity of individual populations, the low population density of $P$. krempfii and the humid environment have limited gene flow and led to a certain degree of population differentiation. These findings indicate that even species with a very limited distribution may harbor genetically differentiated populations.

\section{Conservation considerations}

The main objective in any plant genetic resource conservation program should be to 
maintain the highest possible level of genetic variability (Karp, 1997). According to the results of our field survey, anthropogenic activities, such as overexploitation and deforestation, have undoubtedly influenced the natural habitats and reduced the area of $P$. krempfii distribution.

The very low genetic polymorphism in the Hon Giao population and the restricted distribution of $P$. krempfii suggest that the population is exposed to a considerable risk of extinction. Although most of the extant populations of $P$. krempfii are currently under legal protection in national parks in Vietnam, they face serious threat and risk of extinction by stochastic processes because of their small size. Population size is the most important of five criteria for listing species as endangered under the IUCN system (Thomas et al., 2013), and the loss of genetic variation may decrease the potential for a species to persist through biotic and abiotic changes. Thus, efforts should be made to increase the genetic diversity and population size of $P$. krempfii. P. krempfii does not form pure forests and typically occurs as small groups of 10-30 trees in dense subtropical forests (Luu and Thomas, 2004). We have assessed the ability of $P$. krempfii to seed, germinate, and grow of seedling at the four collected sites. The results showed a high ratio of germinated seeds and seedlings were detected in $P$. krempfii populations. However, only a very low percentage of them develop into trees with a height of $2 \mathrm{~m}$ (data not shown). The reason for this is a lack of nutrition, as gaps (up to $50 \mathrm{~cm}$ in diameter) are often formed in the humus layer, as well as topography fractures.

A loss of habitat may have decreased the population size of $P$. krempfii in the past and could prevent recovery of populations in the future. Therefore, the first effort to recover the extant $P$. krempfii populations should be the protection and restoration of the habitat that $P$. krempfii is adapted to. In situ conservation alone, however, cannot conserve and recover the species, because of the restricted distribution of $P$. krempfii. The results of the most recent assessment by Thomas et al. (2013) highlighted the most serious long term threat to $P$. krempfii as being habitat fragmentation resulting from infrastructure developments, increasing incidence of fires throughout the region, conversion of lower altitude forests to fire-prone $P$. kesiya forests, and encroachment into protected areas for coffee production. In addition, illegal logging aimed at P. krempfii in Chu Yang Sin has recently been reported (Thomas et al., 2013). Therefore, ex situ conservation should also be given high priority to offset habitat deterioration and fragmentation. In this regard, introductions can be designed to establish self-sustaining wild populations, and this practice should be carried out in suitable habitats. Thus, traditional breeding practices, such as controlled crosses between genetically distinct populations, even between individuals of the same stand, could be helpful to restore and enrich genetic diversity of $P$. krempfii. Controlled crosses are important genetic tools for both breeding and conservation of wild populations of economically and ecologically important plant species.

To preserve Vietnam's valuable and unique flat-needle pine and its genetic resources, given the current conservation situation, we recommend a combination of conservation measures that include ex situ and in situ conservation. First, it is necessary to closely control the growth of seedlings on site to ensure the permanent contact of their roots and the soil. Second, we recommend the construction of a core germplasm repository and the collection of germplasm resources in greater breadth and depth. This will allow the seeds to be collected and exchanged between populations, increasing the genetic diversity in each area, and conserving the scarce germplasm resources through natural regeneration. In fact, more attention should be given to ex situ efforts because it would be difficult to implement in situ conservation for all the populations due to the large distribution area and dispersal. Third, in situ conservation should be implemented immediately. Given their high level of genetic diversity and desirable 
growth patterns in their original habitat, populations in Yang Ly, Hon Giao, and Cong Troi of Lam Dong Province and Chu Yang Sin of Dak Lak Province should be assigned high priority. Additionally, the genetic diversity of the two subgroups identified here should be protected, and a priority conservation measure should be instituted for the population in Chu Yang Sin. These measures should include the establishment of nature reserves and forest reservations, and prevention of illegal exploitation. Fourth, seed collection activity using wild resources should be promoted and controlled, and the development of cultivated P. krempfii resources should be encouraged.

\section{ACKNOWLEDGMENTS}

Research supported by the Tay Nguyen 3 Program (Project code TN3/T15). The authors gratefully acknowledge the assistance of Bidoup Nui Ba National Park (Lam Dong Province) and Chu Yang Sin National Park (Dak Lak Province) from Vietnam for providing research samples.

\section{REFERENCES}

Boys J, Cherry M and Dayanandan S (2005). Microsatellite analysis reveals genetically distinct populations of red pine (Pinus resinosa, Pinaceae). Am. J. Bot. 92: 833-841.

Brodribb TJ and Field TS (2008). Evolutionary significance of a flat-leaved Pinus in Vietnamese rainforest. New Phytol. 178: 201-209.

Chiang YC, Shih HC, Chang LW, Li WR, et al. (2011). Isolation of 16 polymorphic microsatellite markers from an endangered and endemic species, Podocarpus nakaii (Podocarpaceae). Am. J. Bot. 98: e306-e309.

Cipriano J, Carvalho A, Fernandes C, Gaspar MJ, et al. (2013). Evaluation of genetic diversity of Portuguese Pinus sylvestris L. populations based on molecular data and inferences about the future use of this germplasm. J. Genet. 92: e41-e48.

Clark CM, Wentworth TR and O'Malley DM (2000). Genetic discontinuity revealed by chloroplast microsatellites in eastern North American Abies (Pinaceae). Am. J. Bot. 87: 774-782.

Echt CS, May-Marquardt P, Hseih M and Zahorchak R (1996). Characterization of microsatellite markers in eastern white pine. Genome 39: 1102-1108.

Echt CS, Vendramin GG, Nelson CD and Marquardt P (1999). Microsatellite DNA as shared genetic markers among conifer species. Can. J. For. Res. Rev. Can. Rech. For. 29: 365-371.

Elsik CG, Minihan VT, Hall SE, Scarpa AM, et al. (2000). Low-copy microsatellite markers for Pinus taeda L. Genome 43: 550-555.

Feng FJ, Han SJ and Wang HM (2006). Genetic diversity and genetic differentiation of natural Pinus koraiensis population. J. For. Res. 17: 21-24.

Goudet J (1995). FSTAT (version 1.2): a computer program to calculate F-statistics. J. Hered. 86: 485-486.

Karp A (1997). Molecular tools in plant genetic resources conservation: A guide to the technologies (No. 2). Biodiversity International, Rome.

Labra M, Grassi F, Sgorbati S and Ferrari C (2006). Distribution of genetic variability in southern populations of Scots pine (Pinus sylvestris) from the Alps to the Apennines. Flora 201: 468-476.

Lecomte H (1921). Un pin remarquable de l'Annam. Bull. Mus. Nation. Hist. Nat. Paris 27: 191-192.

Liu GF, Dong JX, Jiang Y, Lu YF, et al. (2005). Analysis of genetic relationship in 12 species of Section Strobus with ISSR markers. J. For. Res. 16: 213-215.

Luu NDT and Thomas PI (2004). Conifers of Vietnam. Agricultural Publishing, Hanoi.

Mellick R, Porter C and Rossetto M (2009). Isolation and characterisation of polymorphic microsatellite loci from Podocarpus elatus (Podocarpaceae). Mol. Ecol. Res. 9: 1460-1466.

Mosca E, Eckert AJ, Liechty JD, Wegrzyn JL, et al. (2012). Contrasting patterns of nucleotide diversity for four conifers of Alpine European forests. Evol. Appl. 5: 762-775.

Nei M (1972). Genetic distance between populations. Am. Nat. 72: 1590-1597.

Nguyen HN (1993). Two-flat-needle pine endemic to Vietnam. Forest. Rev. 32: 10-11.

Nguyen TH and Vidal JE (1996). Flore du Cambodge, du Laos et du Vietnam. 28: Gymnospermae. Museum National d'Histoire Naturelle, Paris. 
Nhung LTH, Thuy TT, Tam NT, Phong DT, et al. (2014). Flavonoids and their biological activities from the rootbark of Pinus krempfii Lecomte. Viet. J. Chem. 51:22-26.

Parks M, Cronn R and Liston A (2012). Separating the wheat from the chaff: mitigating the effects of noise in a plastome phylogenomic data set from Pinus L. (Pinaceae). BMC Evol. Biol. 12: 100.

Peakall R and Smouse PE (2006). GENALEX 6: Genetic Analysis in Excel. Population genetic software for teaching and research. Mol. Ecol. Notes 6: 288-295. (DOI 10.1111/j.1471-8286.2005.01155.x) [Freely available from The Australian National University, Canberra, Australia (http://www.anu.edu.au/BoZo/GenAlEx/)].

Porebski S, Bailey LG and Baum BR (1997). Modification of a CTAB DNA extraction protocol for plants containing high polysaccharide and polyphenol components. Plant Mol. Biol. Rep. 15: 8-15.

Rubio-Moraga A, Candel-Perez D, Lucas-Borja ME, Tiscar PA, et al. (2012). Genetic diversity of Pinus nigra Arn. populations in southern Spain and northern Morocco revealed by inter-simple sequence repeat profiles. Int. J. Mol. Sci. 13: 5645-5658.

Slatkin M (1985). Gene flow in natural populations. Ann. Rev. Ecol. Syst. 16: 393-430.

Smith D and Devey ME (1994). Occurrence and inheritance of microsatellites in Pinus radiate. Genome 37: 977-983.

Soranzo N, Provan J and Powell W (1999). An example of microsatellite length variation in the mitochondrial genome of conifers. Genome 42: 158-161.

Tam NM, Duy VD, Xuan BTT and Duc NM (2013). Genetic variation and population structure in Chinese water pine (Glyptostrobus pensilis): A threatened species. Ind. J. Biotechnol. 12: 499-503.

Thomas P, Nguyen TH, Phan KL and Nguyen QH (2013). Pinus krempfii. The IUCN Red List of Threatened Species. Version 2015.2. Available at [www.iucnredlist.org]. Accessed July 6, 2015.

Turner IM (2001). The ecology of trees in the tropical rain forest. Cambridge University Press, Cambridge.

Vendramin GG, Lelli L, Rossi P and Morgante M (1996). A set of primers for the amplification of 20 chloroplast microsatellites in Pinaceae. Mol. Ecol. 5: 595-598.

Vu VD (1996). Vietnam Forest Trees. Forest Inventory and Planning Institute, Agricultural Publishing House, Hanoi.

Wang B, Khalili Mahani M, Ng WL, Kusumi J, et al. (2014). Extremely low nucleotide polymorphism in Pinus krempfii Lecomte, a unique flat needle pine endemic to Vietnam. Ecol. Evol. 4: 2228-2238.

Wang MB and Hao ZZ (2010). Rangewide genetic diversity in natural populations of Chinese pine (Pinus tabulaeformis). Biochem. Genet. 48: 590-602.

Wang XR, Szmidt AE and Nguyen HN (2000). The phylogenetic position of the endemic flat-needle pine Pinus krempfii (Pinaceae) from Vietnam, based on PCR-RFLP analysis of chloroplast DNA. Plant Syst. Evol. 220: 21-36.

Willyard A, Syring J, Gernandt DS, Liston A, et al. (2007). Fossil calibration of molecular divergence infers a moderate mutation rate and recent radiations for Pinus. Mol. Biol. Evol. 24: 90-101.

Yang CP, Wei L, Jiang J, Liu GF, et al. (2005). Analysis of genetic diversity for nineteen populations of Pinus sibirica Du Tour with technique of ISSR. J. Northeast For. Univ. 33: 1-3.

Yeh FC, Yang R and Boyle T (1999). POPGENE Microsoft Windows-based freeware for population genetic analysis. Release 1.31. University of Alberta, Edmonton.

Zhang ZY, Chen YY and Li DZ (2005). Detection of low genetic variation in a critically endangered Chinese pine, Pinus squamata, using RAPD and ISSR markers. Biochem. Genet. 43: 239-249. 